\title{
FASILITAS SANITASI DI PASAR WONOKROMO SURABAYA TAHUN 2013
}

\author{
Dewi Anisa, Rusmiati, Darjati
}

\begin{abstract}
A market is the place for the sale and purchase of goods with more than one merchant. It includes shopping centers, traditional markets, shops, malls, palazas, trade centers or other designations. Sanitation conditions are among the important factors in the running of market and poor hygiene may result in a wide range of unfavorable consequences, such as transmission of diseases and vector development. The purpose of the present study was to assess conditions of sanitary facilities, including locations, buildings, sanitation, clean and healthy behavior (CHB), security and other facilities of Wonokromo Market Surabaya.

The study was a descriptive research. Data were collected by observations, interviews and measurements using a healthy market form. Variables included location, buildings, clean water bathrooms and toilets, waste management, drainage, sinks, animal-borne diseases of vectors, CHB of the merchants and market management, market disinfections, security and other facilities. Data were calculated for percentage and assingned to healthy, less healthy and unhealthy categories.

In overall, conditions of sanitation facilities of Wonokromo Market Surabaya were categorized as unhealthy with a score of 5698 out of a variables, the variables locations and security were categorized as less healthy (66\%, 60\% and $64 \%$, respectivety) and the variable other facilities was categorized as unhealthy (56\%).

It is recommended to check, improve and add sanitation facilities or other facilities in accordance with Regulation of the Health Minister No.519/Menkes/SK/VI/2008 on Guidelines for Implementation of Health Markets.
\end{abstract}

\section{Keywords : Sanitation Facilities, market}

\section{PENDAHULUAN}

Pasar tradisional adalah pasar yang sebagian besar dagangannya adalah kebutuhan dasar sehari - hari dengan praktek perdagangan yang masih sederhana dengan fasilitas infrastrukturnya juga masih sangat sederhana dan belum mengindahkan kaidah kesehatan (Kepmenkes RI No 519 tahun 2008).

Pasar Wonokromo termasuk kedalam pasar kelas utama. Lantai Dasar Bawah (LDB) menjual daging, ikan, sayur, sembako, dan lain-lain. Lantai Dasar Atas (LDA) menjual pakaian, perhiasan, dan depot.

Berdasarkan hasil survei pendahuluan ditemukannya fasilitas sanitasi yang belum memenuhi syarat. Kebersihan yang kurang terjaga dengan menumpuknya sampah diberbagai tempat di Pasar Wonokromo. Ditemukan pula keadaan lantai yang basah dan becek yang juga dapat menimbulkan kecelakaan.

Banyaknya pedagang dan pengunjung yang melakukan kegiatan di Pasar Wonokromo mengakibatkan jumlah sampah yang semakin banyak, terutama pada lantai dasar bawah. Tetapi hal ini tidak didukung dengan sarana tempat sampah yang memadai.
Saluran air kotor pada Pasar Wonokromo yang menggunakan sistem terbuka juga dipenuhi oleh sampah dan saluran tidak berjalan dengan lancar.

Oleh karena itu penelitian ini bertujuan untuk Mengetahui kondisi fasilitas sanitasi di Pasar Wonokromo Surabaya tahun 2015 mengacu Kepmenkes RI Nomor 519/MENKES/SK/VI/ 2008.

\section{METODE PENELITIAN}

Jenis penelitian

Jenis penelitian ini termasuk deskriptif yakni menggambarkan kondisi fasilitas sanitasi.

\section{Variabel penelitian}

Variabel penelitian dalam penelitian ini meliputi lokasi pasar, bangunan pasar, air bersih, kamar mandi dan toilet, pengelolaan sampah, sarana pembuangan air kotor, tempat cuci tangan, binatang penular penyakit atau vektor, desinfeksi pasar, PHBS pedagang dan pengelola, pemadam kebakaran, keamanan, tempat atau sarana ibadah, tempat penjual unggas hidup, dan pos pelayanan kesehatan. 


\section{HASIL PENELITIAN DAN PEMBAHASAN}

Tabel 1.

Hasil Rekapitulasi Kondisi Sanitasi Pasar Wonokromo Surabaya Tahun 2015

\begin{tabular}{|c|c|c|c|c|c|}
\hline \multirow[b]{2}{*}{ No } & \multirow[b]{2}{*}{ Variabel } & \multicolumn{2}{|c|}{ Hasil penilaian } & \multirow[b]{2}{*}{$\%$} & \multirow[b]{2}{*}{$\mathrm{K}$} \\
\hline & & $\begin{array}{l}\text { Skor } \\
\max \end{array}$ & $\begin{array}{l}\text { Skor yang } \\
\text { diperoleh }\end{array}$ & & \\
\hline 1 & Lokasi & 500 & 500 & $100 \%$ & $\mathrm{~S}$ \\
\hline \multirow[t]{9}{*}{2} & Bangunan & 2000 & 1328 & $66 \%$ & KS \\
\hline & a. Umum & 50 & 50 & $100 \%$ & S \\
\hline & b. Penataan ruang dagang & 400 & 400 & $100 \%$ & $\mathrm{~S}$ \\
\hline & $\begin{array}{l}\text { C. Ruang Kantor } \\
\text { Pengelola }\end{array}$ & 50 & 40 & $80 \%$ & $\mathrm{~S}$ \\
\hline & d. Tempat penjualan bahan pangan basah & 400 & 92 & $23 \%$ & TS \\
\hline & e. Tempat penjualan bahan pangan kering & 300 & 150 & $50 \%$ & TS \\
\hline & f. Tempat penjualan makanan matang siap saji & 300 & 129 & $43 \%$ & TS \\
\hline & g. Area Parkir & 100 & 100 & $100 \%$ & $S$ \\
\hline & h. Konstruksi & 400 & 365 & $91 \%$ & $S$ \\
\hline \multirow[t]{8}{*}{3} & Sanitasi & 2600 & 1560 & $60 \%$ & KS \\
\hline & a. Air Bersih & 400 & 400 & $100 \%$ & $S$ \\
\hline & b. Kamar mandi dan toilet & 400 & 280 & $70 \%$ & KS \\
\hline & c. Pengolahan sampah & 400 & 264 & $66 \%$ & KS \\
\hline & d. Drainage & 400 & 200 & $50 \%$ & TS \\
\hline & e. Tempat cuci tangan & 400 & 0 & $0 \%$ & TS \\
\hline & f. Binatang penular penyakit & 300 & 120 & $50 \%$ & TS \\
\hline & g.Desinfeksi pasar & 300 & 300 & $100 \%$ & $\mathrm{~S}$ \\
\hline \multirow[t]{3}{*}{4} & PHBS & 2000 & 1280 & $64 \%$ & KS \\
\hline & a. Pedagang & 1500 & 780 & $52 \%$ & TS \\
\hline & b. Pengelola & 500 & 500 & $100 \%$ & $\mathrm{~S}$ \\
\hline \multirow[t]{3}{*}{5} & Keamanan & 500 & 470 & $94 \%$ & $\mathrm{~S}$ \\
\hline & a. Pemadam Kebakaran & 300 & 270 & $90 \%$ & $\mathrm{~S}$ \\
\hline & b. Keamanan & 200 & 200 & $100 \%$ & $\mathrm{~S}$ \\
\hline \multirow[t]{5}{*}{6} & Fasilitas lain & 1000 & 560 & $56 \%$ & TS \\
\hline & a. Tempat ibadah & 200 & 160 & $80 \%$ & $\mathrm{~S}$ \\
\hline & b. Tempat penjual unggas hidup & 500 & 250 & $50 \%$ & TS \\
\hline & c. Pos kesehatan & 300 & 150 & $50 \%$ & TS \\
\hline & Jumlah & 8600 & 5698 & $66 \%$ & KS \\
\hline
\end{tabular}

Berdasarkan Tabel 1, hasil rekapitulasi kondisi fasilitas sanitasi Pasar Wonokromo Surabaya masuk kategori pasar kurang sehat $(66 \%)$. Disebabkan beberapa faktor yang kurang memenuhi syarat, seperti

a. Tempat Penjual Bahan Pangan Basah

1. Pedagang menggunakan telenan dari kayu dan masih ditemukan sisa - sisa daging di sela - sela telenan.

2. Tidak tersedia tempat pencucian bahan pangan dan peralatan.

3. Tidak terdapat fasilitas tempat cuci tangan yang dilengkapi sabun.

4. Saluran pembuangan limbah dalam keadaan terbuka, bau, dan tersumbat.

5. Tidak terdapat pemisah tempat sampah basah dan kering.

6. Vektor lalat dan tikus ditemukan pada penjual bahan pangan basah. b. Tempat Penjualan Bahan Makanan Kering

1. Tidak terdapat pemisah tempat sampah basah dan kering.

2. Tidak terdapat fasilitas tempat cuci tangan.

3. Vektor tikus masih ditemukan dipenjual pedagang bahan makanan kering.

c. Tempat Penjualan Makanan Matang Siap Saji

1. Beberapa Tempat penyajian makanan ditemukan dalam wadah terbuka.

2. Pisau yang digunakan tidak ada pembeda antara bahan makanan mentah dan matang sehingga menyebabkan kontaminasi silang.

3. Tidak terdapat fasilitas tempat cuci tangan yang dilengkapi sabun.

4. Saluran pembuangan air limbah tidak dalam keadaan tertutup yang 
menyebabkan berkumpulnya vektor lalat.

5. Tidak ada pemisah untuk tempat sampah basah dan kering.

d. Kamar mandi dan toilet

Tidak ada pemisah antara toilet laki - laki dan perempuan. Dengan jumlah 2345 pedagang jumlah, kamar mandi yang tersedia adalah 8 lokasi dengan 42 kamar mandi. Menurut persyaratan Kepmenkes RI Nomor 519/MENKES/SK/ VI/2008 untuk 100 jumlah pedagang dibutuhkan 3 kamar mandi jadi seharusnya tersedia 69 kamar mandi.

e. Pengolahan sampah

Tidak setiap kios dan los memiliki tempat sampah dan tidak ada pemisah antara sampah kering dan sampah basah. Hal ini menyebabkan bertumpuknya sampah di dekat kios dan los dan menimbulkan bau. Karena sampah merukapan salah satu masalah penting di pasar.

TPS juga menjadi tempat perindukan vektor seperti lalat, kecoa dan tikus yang dapat menularkan penyakit. Beberapa tempat, khususnya TPS yang dapat menjadi tempat berkembang biak yang baik bagi vektor.

f. Drainage

Saluran pembuangan dari los - los khusus seperti tempat penjualan daging, ikan masih ditemukan dalam keadaan terbuka, beberapa saluran pembuangan ditemukan dalam keadaan tersumbat sampah, tidak lancar dan bau.

Pembersihan dan Penambahan kisi terhadap saluran pembuangan air terutama pada los penjual daging dan bahan makanan basah perlu dilakukan

g. Tempat cuci tangan

Dengan tidak adanya fasilitas cuci tangan, menjadikan perilaku hidup bersih dan sehat pedagang menjadi berkurang. Seharusnya disediakan fasilitas tempat cuci tangan dibeberapa titik.

Salah satu media penular penyakit adalah vektor, dengan masih ditemukannya vektor lalat, kecoa dan tikus dapat mengakibatkan penularan penyakit. Los makanan siap saji dan bahan pangan belum secara meyeluruh terbebas dari lalat, kecoa dan tikus.

Sulit dihindari pasar erat kaitannya dengan keberadaan vektor karena banyak tempat yang dapat menjadi tempat perindukan. Keberadaan tikus juga ditemukan dilos dan kios pedagang.

h. Perilaku Hidup Bersih Dan Sehat

Penilaian perilaku hidup bersih dan sehat meliputi cuci tangan dengan sabun, tidak merokok saat berjualan, tidak membuang sampah sembarangan, dan tidak meludah dan buang dahak sembarangan. Kurangnya tingkat pengetahuan tentang perilaku hidup bersih dan sehat, merupakan indikator utama.

Perilaku pedagang yang membuang sampah sembarangan, diketahui dari sampah - sampah yang masih bertumpuk di depan los dan kios pedagang. Selain itu perilaku membuang dahak dan merokok juga masih ditemukan khususnya pedagang pria.

i. Tempat Penjual Unggas Hidup Tidak ada akses masuk dan keluarnya kendaraan pengangkut tidak tersendiri dan tempat penampung unggas tidak terbuat dari bahan yang kuat. Kondisi tempat penjual unggas dalam keadaan kotor dan tidak terawat.

j. Pos Pelayanan Kesehatan

Tidak memiliki pos kesehatan untuk pedagang, pembeli dan pengelola jika mengalami sakit atau kecelakaan.

\section{KESIMPULAN DAN SARAN}

\section{Kesimpulan}

Berdasarkan hasil penilaian kondisi fasilitas sanitasi di Pasar Wonokromo Surabaya Tahun 2015 masuk kategori pasar kurang sehat(66\%).

1. Lokasi masuk kategori sehat(100\%).

2. Bangunan masuk kategori kurang sehat(66\%).

3. Sanitasi masuk kategori kurang sehat $(61 \%)$.

4. Perilaku Hidup Bersih dan Sehat masuk kategori kurang sehat(64\%).

5. Keamanan masuk kategori sehat(94\%).

6. Fasilitas Lain masuk kategori tidak sehat(56\%).

\section{Saran}

1. Untuk pengelola pasar

a. Disediakan fasilitas tempat cuci tangan yang dilengkapi sabun.

b. Disediakan tempat pencucian peralatan dengan air mengali

c. Tersedia toilet laki - laki dan perempuan secara terpisah dan terdapat petunjuk yang jelas

d. Menyediakan tempat sampah yang terpisah antara sampah basah dan sampah kering dengan penutup.

e. Pembersihan TPS secara berkala dan pemasangan perangkap tikus.

f. Saluran pembuangan yang tersumbat dibersihkan kemudian diberi tutup.

g. Disediakan akses masuk dan keluarnya kendaraan pengangkut unggas tersendiri.

h. Disediakan pos pelayan kesehatan. 
2. Untuk pedagang

a. Pedagang menjaga kebersihan alat, tempat dan lingkungan.

b. Sebaiknya ikan segar, daging, sayur disimpan dalam alat pendingin atau menggunakan es batu.

c. Setiap kios dan los menyediakan tempat sampah basah dan tempat sampah kering yang dilengkapi penutup.

d. Menggunakan APD khususnya pedagang makanan basah dalam aktivitas jual beli.

e. Berperilaku hidup bersih dan sehat selama berjualan.

\section{DAFTAR PUSTAKA}

Adnani, Hariza, 2011. I/mu Kesehatan Masyarakat. Yogyakarta: Nuha Medika

Candra, Budiman, 2007. Pengantar Kesehatan Lingkungan. Jakarta : EGC

Depkes RI, 2011. Pedoman Pembinaan Perilaku Hidup Bersih dan Sehat. Jakarta.

Frick, Heinzdan Tri Hesti Mulyani, 2006. Arsitektur Ekologis : Kanisius

Keputusan Menteri Kesehatan Republik Indonesia nomor:519/MENKES/SK/VI/2008

Tentang Pedoman Penyelenggaraan Pasar Sehat

Mubarak, Wahid Iqbal dan Nurul Chayatin. 2009. Ilmu Kesehatan Masyarakat : Teori dan Aplikasi . Jakarta : Salemba Medika

Mukono, 2010. Prinsip Dasar Kesehatan Lingkungan. Jakarta, Airlangga University Press Mulia, R.M, 2005. Kesehatan Lingkungan. Yogyakarta, Graha Ilmu.

Notoatmodjo, Soekidjo, 2011. Kesehatan Masyrakat IImu dan Seni. Jakarta: Rineka Cipta

Notoatmojo, Soekidjo, 2010. Metode Penelitian Kesehatan. Jakarta, Rineka Cipta

Peraturan Presiden Nomor 112 tahun 2007 tentang Penataan dan Pembinaan Pasar Tradisional, Pusat Perbelanjaan dan Toko Modern

Proverawati, A., Rahmawati, E.2012. Perilaku Hidup Bersih dan Sehat (PHBS). Yogyakarta, Nuha Medika : hal 19.

Saruji, Didik, 2001. Kesehatan Lingkungan. Bandung, Karya Putri Darwati

Sudrajat, H.R, 2009. Mengelola Sampah Kota: Solusi Mengatasi Masalah Sampah Kota dengan Manajemen Terpadu dan Mengolahnya menjadi
Energi Listrik dan Kompos. Jakarta : Penebar Swadaya

Suparlan, 2012. Pedoman pengawasan sanitasi tempat- tempat umum. Surabaya, percetakan Dua tujuh. Cetakan 3

Suyono, Budiman, 2010. Ilmu Kesehatan Masyarakat dalam Konteks Kesehatan Lingkungan. Jakarta, Buku Kedokteran EGC.

Tim Penulis Penebar Swadaya, 2011. Penanganan dan Pengolahan Sampah. Jakarta: Penebar Swadaya

Tosepu, Ramadhan, 2010. Kesehatan Lingkungan. Surabaya: Bintang Surabaya

Wiarto, Giri. 2013. Budaya Hidup Sehat. Surakarta, Gosyen Publishing.

Widoyoko, E.P, 2014. Teknik Penyusunan Instrumen Penelitian. Yogyakarta, Pustaka Belajar. Cetakan Ketiga: hal 104-115. 